\title{
ANALISA HIDRO OSEANOGRAFI PULAU LIWUNGAN UNTUK STUDI KELAYAKAN STRUKTUR DERMAGA APUNG
}

\section{HYDRO-OCEANOGRAPHY ANALYSIS OF LIWUNGAN ISLAND FOR THE SUITABILITY OF FLOATING JETTY STRUCTURE}

\author{
Agus Sufyan', Rudhy Akhwady ${ }^{1}$, Johan Risandi' ${ }^{1}$ dan Nurfitri Syadiah² \\ ${ }^{1}$ Pusat Riset Kelautan, \\ Badan Riset dan Sumber Daya Manusia Kelautan dan Perikanan \\ ${ }^{2}$ Direktorat Perencanaan Ruang Laut \\ e-mail : agussufyan@gmail.com \\ Diterima tanggal: 14 April 2017 ; diterima setelah perbaikan: 7 Mei 2017 ; Disetujui tanggal: 12 Desember 2017
}

\begin{abstract}
ABSTRAK
Kajian hidro oseanografi digunakan untuk menentukan lokasi penempatan dermaga apung yang sesuai di Pulau Liwungan Kabupaten Pandeglang-Jawa Barat. Dermaga apung di pulau tersebut nantinya akan digunakan sebagai pendukung kegiatan wisata bahari. Penggunaan dermaga apung dipilih karena mempunyai beberapa keunggulan dibandingkan dengan dermaga konvensional, utamanya dari segi biaya dan kemudahan pemasangan. Akan tetapi, dermaga jenis ini mememerlukan kondisi fisik perairan yang spesifik. Pada studi ini, dilakukan analisa terhadap faktor fisik perairan yang berpengaruh, yaitu kondisi gelombang dan pasang surut, melalui pengamatan lapangan dan pemodelan numerik dengan MIKE 21. Gelombang signifikan pada perairan Liwungan berkisar 1,1-2 meter dengan rata-rata 1,8 m. Pasang surut mempunyai tinggi tunggang 1,66 meter, dengan tipe pasang surut campuran condong ke harian ganda. Hasil analisa menunjukkan letak perairan yang sesuai untuk penempatan dermaga apung berada di bagian tenggara pulau Liwungan dengan dasar perairan yang relatif lebih curam dengan kemiringan $8,5^{\circ}$. Lokasi tersebut relatif terlindung dari serangan gelombang dengan tinggi gelombang maksimum pada titik pemasangan dermaga apung hanya 1,35 meter (periode ulang 25 tahun).
\end{abstract}

Kata kunci: Hidro-Oseanografi, Liwungan, dermaga apung, software MIKE 21

\section{ABSTRACT}

Hydro-oceanography analysis was carried out to determine suitable location for a floating jetty in Liwungan Island, Pandeglang Regency-West Java. The floating jetty will be used to support marine tourism activities. Floating jetties have advantages compared to conventional jetty (fix jetty), mainly related to the cost factor and the easiness of installation. However, this typical jetty needs to be placed on a specific area. In this study, the physical characteristics influencing the suitability, i.e. waves and tides were examined through measuring campaign and MIKE 21 numerical model. Significant waves ranged 1,1 to $2 \mathrm{~m}$ with averge of $2 \mathrm{~m}$. Meanwhile, tidal range is 1,66 $\mathrm{m}$ and categorized as mixed tide prevailing semidiurnal. The analysis showed South-East part of the island is the most suitable area for floating jetties. The area has a better steepness (slope $\sim 8.5^{\circ}$ ) and relatively protected from waves attack compared to other part of the island. The possible maximum wave height, from 25 year return period analysis, on that location is $1,35 \mathrm{~m}$.

Keywords: Hydro-oceanography, Liwungan, Floating Jetty, Software MIKE 21

Analisa Hidro Oseanografi Pulau Liwungan Untuk Studi Kelayakan Struktur Dermaga Apung - Agus Sufyan, Rudhy Akhwady, Johan Risandi, dan Nurfitri Syadiah 


\section{PENDAHULUAN}

Dermaga apung atau floating jetty adalah struktur untuk menambatkankapal padapontonyangmengapung diatas air. Dermaga apung digunakan untuk menyesuaikan beda ketinggian terhadap pasang surut air laut, sungai maupun danau sehingga dengan menggunakan dermaga apung maka ketinggian kapal dengan dermaga selalu sesuai (Globalmitrateknik, 2017). Dermaga apung merupakan salah satu infrastruktur modern pendukung transportasi laut yang dapat memberikan manfaat ekonomi bagi pengembangan pulau kecil, khususnya untuk mendukung pariwisata. Keberadaan dermaga apung di pulau kecil akan memudahkan naik turunnya wisatawan. Dermaga apung memiliki kelebihan pada kemudahan proses pemasangan serta biaya relatif lebih murah dibandingkan dengan dermaga konvensional yang membutuhkan proses instalasi cukup lama serta biaya mahal. Struktur utama dermaga apung terdiri dari bagian terapung (pontoon) yang biasanya terbuat dari kombinasi plastik HDPE (High Density Poly Ethylen), kayu, baja dan beton (Globalmitrateknik, 2017).

Secara umum, dermaga apung mempunyai beberapa keterbatasan, antara lain konstruksinya secara umum tidak sekuat dermaga konvensional, utamanya pada bagian yang bergerak seperti jembatan fleksibel dan ponton. Untuk itu, dermaga apung sebaiknya dipasang pada perairan yang terlindung dari gelombang tinggi dengan arus yang kecil (Sciortino, 2010). Karena gaya-gaya yang ada di laut seperti gelombang sangat rentan untuk membuat struktur tidak stabil. Struktur yang tidak stabil dapat mengalami pergerakan yang sangat besar sehingga menyebabkan struktur terguling dan tenggelam (Watanabe et al., 2004). Kajian terkait dermaga apung dan karakteristik gelombang sudah dilakukan oleh beberapa peneliti, diantaranya : Aspek desain pemecah gelombang dan dermaga apung dengan menggunakan system modular (Hakiki \& Samsakerta, 2016); Karakteristik gelombang di perairan kalianget Kabupaten sumenep (Syarifuddin dkk., 2016); Studi karakteristik gelombang pada daerah pantai matani satu. (Umpel dkk., 2015); studi gelombang untuk kelayakan pengembangan budidaya laut (Risandi dkk., 2015).

Pemerintah Daerah Pandeglang-Banten saat ini sedang mengembangkan wisata bahari untuk meningkatkan pendapatan asli daerah (PAD). Salah satu pulau kecil di wilayah Pandeglang, yaitu Pulau Liwungan, direncanakan untuk dibangun sentra wisata modern. Pulau tersebut terletak sekitar 3,5 $\mathrm{km}$ dari pulau utama (Jawa) dan dapat dijangkau dengan kapal kecil yang banyak terdapat di pelabuhan pendaratan ikan Kecamatan Panimbang, Kabupaten Pandeglang. Pulau ini memiliki luas \pm 50 hektar dengan dasar perairan karang. Obyek wisata di Pulau Liwungan antara lain : berkeliling pulau (tracking), snorkling, diving, mancing, ataupun sekedar berenang dan bermain pasir. Untuk memudahkan akses transportasi wisatawan ke pulau tersebut, Pemerintah Daerah Pandeglang berencana menempatkan dermaga apung disekitar pulau. (Disbudpar, 2013). Pada studi ini, dilakukan kajian aspek hidro oseanografi yang meliputi Analisa kedalaman perairan, pasang surut dan gelombang disekitar perairan Liwungan untuk kebutuhan penempatan dermaga apung. Lebih lanjut, dilakukan pemodelan penjalaran gelombang diperairan tersebut dan divalidasi dengan perhitungan analitik.

\section{BAHAN DAN METODE}

Analisa kesesuaian lokasi pemasangan dermaga apung dilakukan melalui analisa data primer dan sekunder dengan tahapan studi sebagai berikut :

\section{A. Pengambilan Data Primer Batimetri}

Pemetaan kedalaman perairan pada studi dilakukan dengan mengunakan single beam echosounder yang ditempatkan pada sebuah kapal (Saputra dkk., 2016). Pada saat bersamaan, dilakukan pencatatan tinggi muka air dengan rambu ukur pasang surut yang diikat pada benchmark lokal (Poerbandono \& Djunarsjah, 2005; Muldiyatno dkk., 2016).

Hasil pemeruman menunjukkan perairan sekitar Pulau Liwungan tergolong landai dengan kedalaman berkisar antara 0-10 $\mathrm{m}$ dengan kemiringan ratarata 8,5 derajat. Dermaga apung perlu ditempatkan pada lokasi yang selalu tergenang oleh air meskipun pada kondisi surut terendah sehingga dermaga tetap terapung sehingga dapat berfungsi sepanjang tahun dan mencegah terjadinya kerusakan pada badan dermaga. Untuk meningkatkan efisiensi dan menekan biaya, dermaga harus diposisikan sedekat mungkin dengan daratan dan mempertimbangkan kedalaman perairan. Titik penempatan dermaga apung di Pulau Liwungan sebaiknya memiliki kedalaman perairan minimum 1,5 meter ketika surut terendah Lowest Low Water Level (LLWL) dikarenakan kapal perikanan di daerah tersebut berukuran kuran $<15$ GT dan mempunyai rata-rata draft kapal sekitar 1 meter (Gambar 1).

Gaya tarik benda-benda angkasa terutama matahari dan 
bulan terhadap massa air di bumi akan menyebabkan suatu fenomena naik turunnya muka air laut secara berkala yang dinamakan dengan pasang surut (Pariwono, 1989), pengaruh perubahan elevasi muka air laut akibat pasang surut sangat penting untuk diketahui sebagai acuan untuk menentukan posisi elevasi suatu bangunan laut (Muliyati dkk., 2016). Pada perencanaan dermaga apung, informasi pasang surut diperlukan untuk efisiensi kinerja dermaga apung (Chendra. 2017), yaitu :

1. Penentuan surut terendah pada calon lokasi untuk memastikan dermaga selalu terapung sehingga kerusakan akibat kandas ketika surut dapat dihindari

2. Penentuan desain jembatan penghubung ( $\mathrm{ramp}$ ), sehingga ramp tidak terlalu curam yang bisa membahayakan penumpang atau terlalu landai sehingga kurang efisien dan berbiaya mahal.

Elevasi muka air di lokasi studi diperoleh melalui peramalan pasut (Supriyono dkk., 2015). Untuk kalibrasi, dilakukan pengamatan pasang surut di lokasi selama 39 jam menggunakan rambu ukur yang ditempatkan di ujung dermaga pada koordinat 6²9'37.10’'LS - 10543'28.78’BT.

Hasil analisa menunjukkan kesamaan pola antara hasil peramalan dan pengukuran pasang surut dengan RMS Error hanya sebesar $6,631 \%$, sehingga dalam studi ini data hasil peramalan pasut bisa dipakai sebagai input pemodelan hidrooseanografi maupun dasar perencanaan. Analisa konstanta harmonik pasut dan referensi muka air hasil survei disajikan pada Tabel 1 di bawah, dengan bilangan Formzahl yang diperoleh sebesar 0,5311. Dapat dinyatakan bahwa daerah studi mempunyai tipe pasang surut campuran condong ke harian ganda (Pranowo \& Wisasantosa, 2011), seperti yang terlihat pada Gambar 2.

Sebagai titik benchmark (BM) atau titik ikat terhadap elevasi pasang surut digunakan ujung pilar dermaga kayu tempat rambu pasut terpasang (Gambar 3). Titik BM ini yang nantinya akan digunakan sebagai referensi untuk pembangunan dermaga apung di Pulau Liwungan (Arifiyanto dkk., 2016).

\section{B. Pengumpulan Data Sekunder}

Data sekunder pada penelitian ini diperoleh dari Badan Meteorologi Klimatologi dan Geofisika (BMKG) berupa data angin dan gelombang tiap jam periode 2005-2015 untuk wilayah perairan Banten yang berasal dari pencatatan Satelit Meteofranc, dan peta batimetri perairan sekitar Pulau Liwungan dari Pushidros TNIAL. Akurasi data, pada studi ini, data angin diambil pada koordinat $-6,364864^{\circ} \mathrm{LS} / 105,658188^{\circ} \mathrm{BT}$ yang berjarak kurang lebih $15 \mathrm{~km}$ dari Pulau Liwungan.

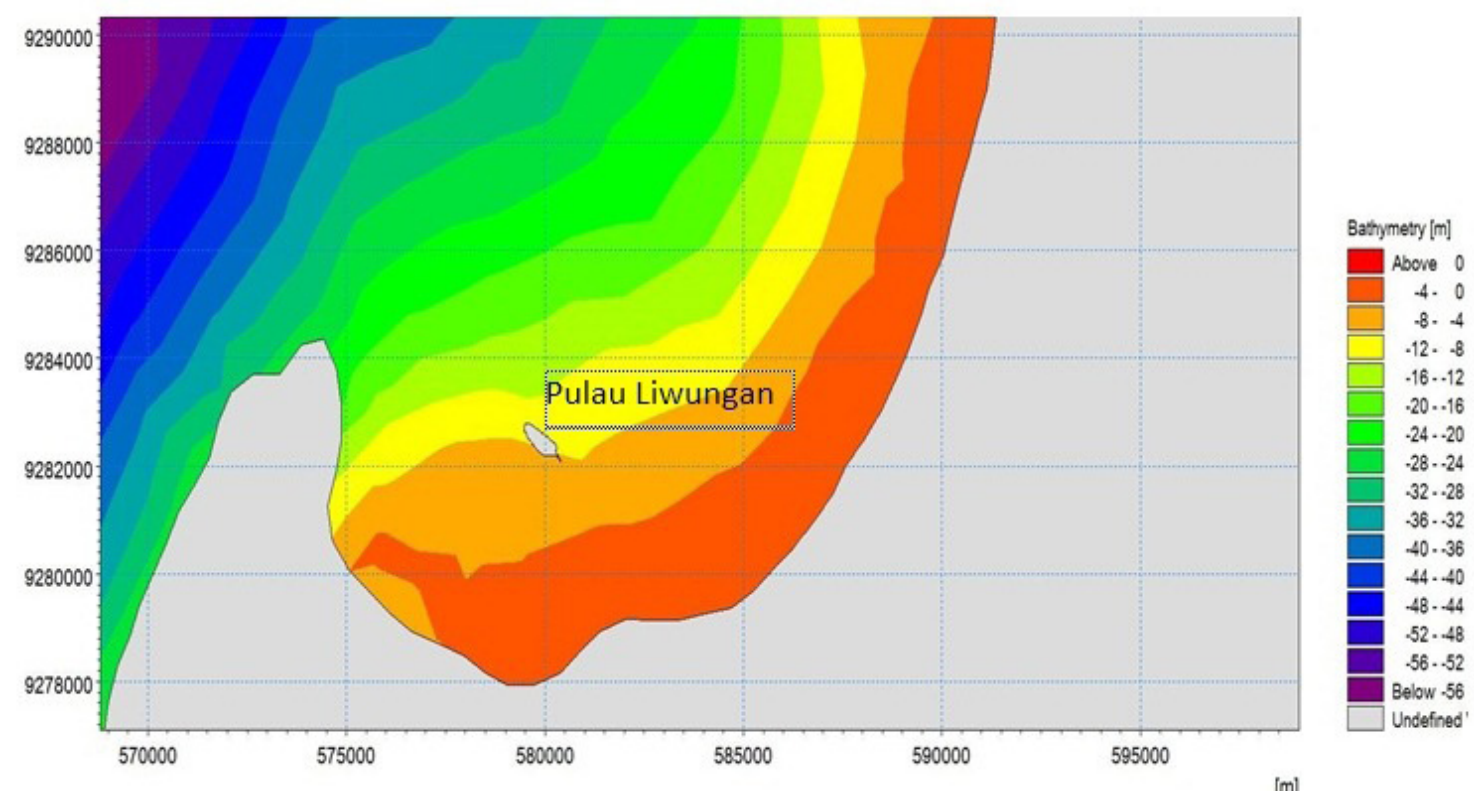

Gambar 1. Bathimetri perairan Pulau Liwungan dan sekitarnya hasil survey laut Figure 1. Bathymetry area of Liwungan Island and marine survey results Sumber: Hasil pengolahan data 


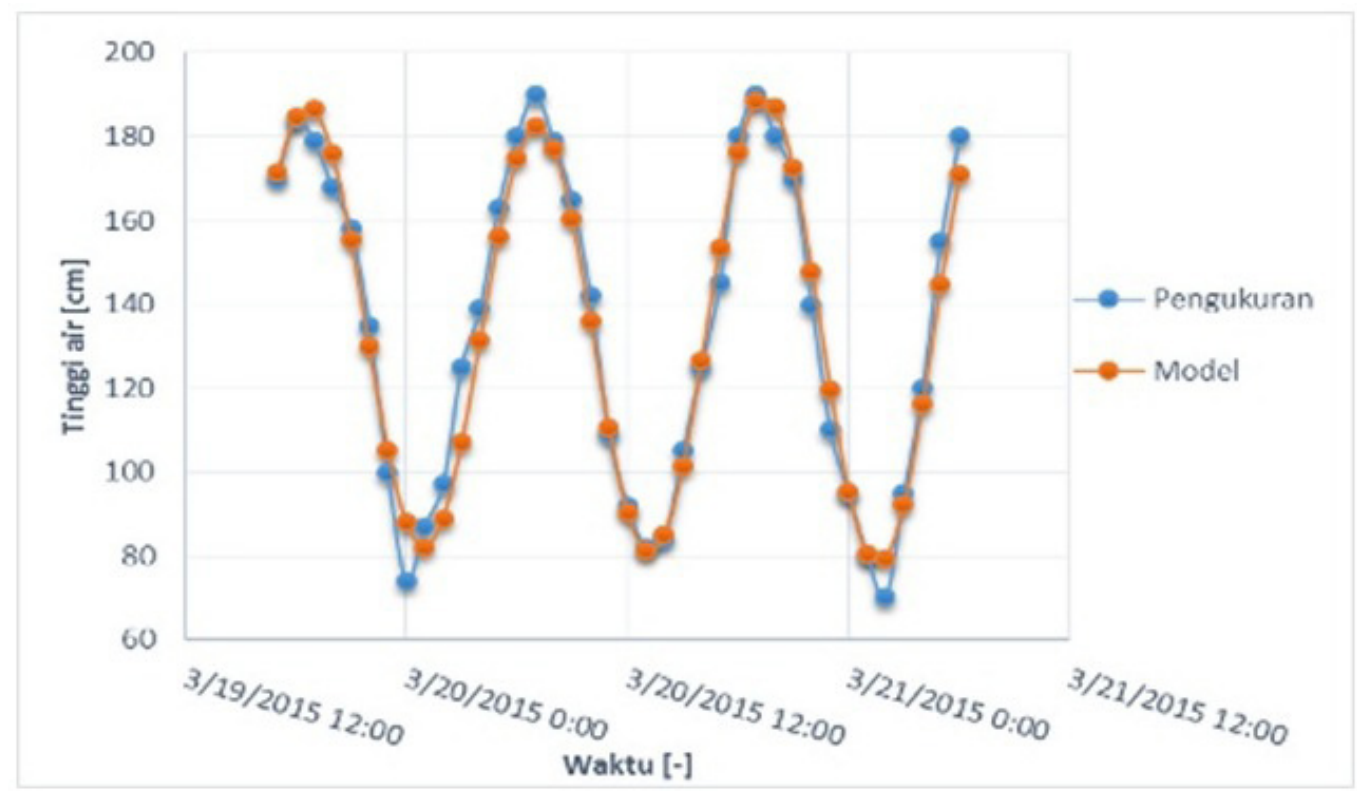

Gambar 2. Pasang Surut Hasil Pengukuran dan Prediksi Model

Figure 2. Tidal Measurement and Model Prediction

Sumber: Hasil pengolahan data

Tabel 1. Parameter Pasang Surut Yang Digunakan Table 1. Tidal Parameters Used

\begin{tabular}{lllll}
\hline Parameter & Amplitudo $[\mathrm{cm}]$ & Fase $\left[{ }^{\circ}\right]$ & Parameter & Tinggi muka air $[\mathrm{cm}]$ \\
\hline M2 & 34,38 & 355,23 & HHWL & 217,98 \\
S2 & 13,48 & 50,35 & MSL / S0 & 135,32 \\
K1 & 15,69 & 162,54 & LLWL & 51,90 \\
O1 & 9,73 & 154,39 & Tunggang & 166 \\
N2 & 7,43 & 329,32 & Tinggi BM & 445 \\
P1 & 4,8 & 160,18 & & \\
K2 & 4,58 & 54,1 & & \\
Q1 & 2,04 & 140,7 & & \\
\hline
\end{tabular}

Sumber: Hasil pengolahan data

\section{Analisa Data Angin dan Gelombang}

Pengolahan data sekunder dilakukan untuk mendapatkan informasi kecepatan angin dan tinggi gelombang yang terjadi pada daerah studi (perairan Pulau Liwungan) sebagai input pada model numerik (Mustikasari dkk., 2015).

Probabilitas kejadian dan arah kedua parameter disajikan dalam bentuk mawar angin dan gelombang. Angin dominan berturut-turut datang dari arah tenggara, dari arah barat dan dari arah barat laut (Gambar 5).

Hasil analisa data gelombang BMKG menunjukkan perairan barat pulau Jawa tergolong slight to moderate berdasar pada Douglas sea scale (Owens, 1982) dengan tinggi gelombang signifikan pada kisaran 1,1
- $2 \mathrm{~m}$ dengan rata-rata $1,8 \mathrm{~m}$. Gelombang dominan datang dari arah Tenggara, barat dan barat laut seperti ditunjukkan pada Gambar 6, dimana arah paling dominan dari arah tenggara dengan tinggi gelombang maksimal sekitar 1,5 meter.

\section{Perkiraan Gelombang Periode Ulang}

Hasil pengolahan data angin BMKG 2005-2015 diperoleh tinggi gelombang representatif : Hs, H1/10, Hmaks dengan beberapa periode ulang. Terdapat beberapa model distribusi untuk memprediksi gelombang dengan periode ulang tertentu, yaitu distribusi Normal, Log-Normal, Gumbel dan Weibull (Kamphuis, 2000). Dalam tulisan ini digunakan metode Weibull untuk menghitung periode ulang gelombang. 


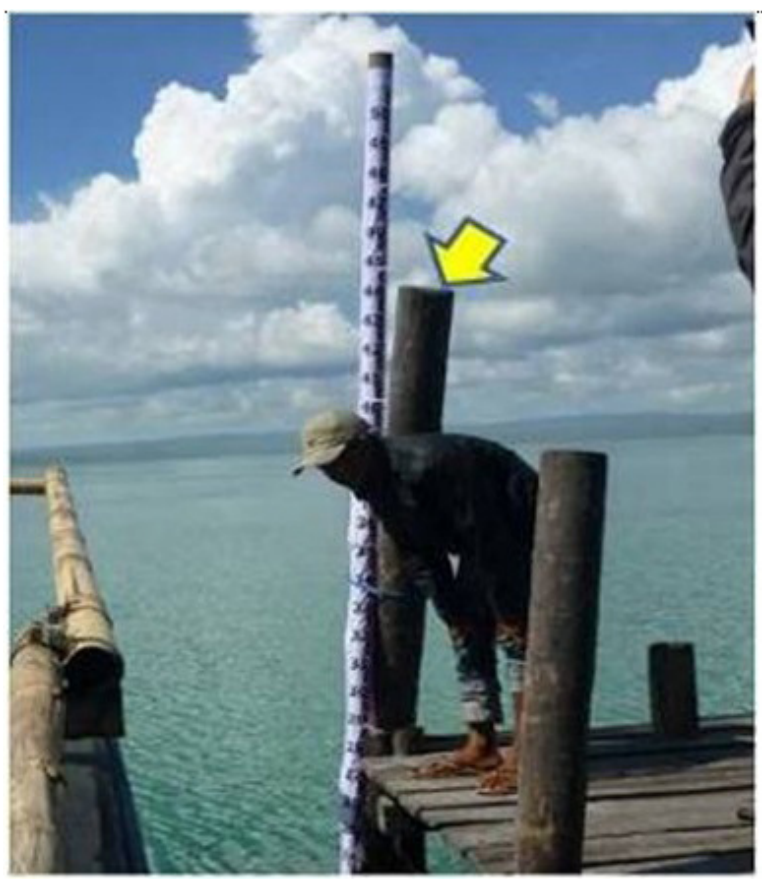

Gambar 3. Rambu pengamatan pasang surut dan benchmark

Figure 3. Signs of tidal observation and benchmark

Sumber: Laporan akhir, 2015

Pada Tabel 2 terlihat tinggi gelombang rencana dititik pengambilan data mencapai 4,47 meter untuk periode ulang 25 tahun, dimana secara umum struktur dermaga apung juga mempunyai umur struktur yang sama.

\section{Deformasi Gelombang Analisa Gelombang Pecah}

Perairan sekitar Pulau Liwungan tergolong landai dengan tinggi gelombang rata-rata 1,8 meter dan periode 6,8 detik, menggunakan persamaan gelombang pecah (Triatmodjo, 1999) maka gelombang pada lokasi pecah pada tinggi gelombang 2 meter dengan kedalaman kira-kira 2,4 meter.

Fenomena gelombang pecah terjadi pada bagian barat Pulau Liwungan yang tidak terlindung, sementara daerah Pulau Liwungan yang menghadap Pulau Jawa, menggunakan teori hubungan fetch dan tinggi gelombang (Karmadibrata, 1985), aman dari kemungkinan serangan gelombang dengan jarak fetch kurang dari $10 \mathrm{~km}$.

\section{Analisa Difraksi}

Secara garis besar, Pulau Liwungan membentuk sudut $120^{\circ}$ terhadap Utara dan pada bagian Timur pulau terdapat gosong pasir dan gugusan karang yang berfungsi sebagai peredam serangan gelombang alami. Difraksi mungkin terjadi ketika gelombang datang dari arah Utara, akan tetapi, gosong pasir yang terbentuk memanjang lebih dari 100 meter meminimalisir efek difraksi pada perairan dekat pulau. Analisa difraksi (Triatmodjo, 1999) menunjukkan pengaruh difraksi pada bagian Timur pulau hanya sekitar $10 \%$ dari gelombang datang.

\section{Pemodelan Gelombang}

Karakteristik gelombang suatu perairan dapat diketahui dengan menggunakan model numerik penjalaran gelombang atau menggunakan metode pengukuran in situ dengan menggunakan wave recorder maupun penginderaan jauh dengan citra dan altimetri (Holthuijsen, 2007). Pemodelan kondisi gelombang di daerah studi dilakukan dengan menggunakan perangkat lunak DHI MIKE untuk 3 arah gelombang datang yang berbeda, yaitu: i) Utara (N), ii) Barat Laut (NW) dan (iii) Barat (W). Pemodelan dilakukan dengan input gelombang periode ulang 25 tahun yang berasal dari analisa data gelombang Selat Sunda pada sub bab sebelumnya, sebagaimana diberikan dalam Tabel 3.

Pemodelan numerik penjalaran gelombang dibuat untuk mensimulasikan mekanisme yang terjadi pada proses transformasi gelombang, diantaranya adalah pendangkalan (shoaling), refraksi, refleksi, difraksi dan gelombang pecah yang terjadi akibat perubahan kedalaman (Young, 1999). 




Gambar 4. Titik pengambilan data angin BMKG

Figure 4. Wind data collection point BMKG

Sumber: Google, 2017

Tabel 2. Hasil perhitungan tinggi (H 1/3) dan periode gelombang (Tp) di perairan Pulau Liwungan Table 2. Results of the calculations in the wave height and period on Liwungan Island area

\begin{tabular}{lll}
\hline Periode Ulang [Th] & H 1/3[M] & Tp[Dtk] \\
\hline 2 & 1.4 & 5.1 \\
5 & 2.3 & 8.3 \\
10 & 3.2 & 11.2 \\
20 & 4.1 & 14.4 \\
25 & 4.47 & 15.4 \\
50 & 5.5 & 19.0 \\
\hline
\end{tabular}

Simulasi pemodelan merupakan kombinasi dari refraksi-difraksi gelombang, friksi gelombang, dan gelombang pecah. Persamaan pengatur yang diselesaikan dalam model refraksi-difraksi adalah persamaan perambatan gelombang yang dimodifikasi dari persamaan gelombang mild-slope dua dimensi. Persamaan gelombang tersebut ditulis sebagai berikut:

$$
\nabla .(\mathrm{C} \mathrm{Cg} \dot{\eta})+(\mathrm{Cg} / \mathrm{C}) \sigma 2 \dot{\eta}=0
$$

Dimana :

$$
\begin{aligned}
& \eta \dot{(x, y)}=\text { fungsi elevasi gelombang yang diestimasi } \\
& \sigma \quad=\text { frekwensi gelombang }(\mathrm{rad} / \mathrm{s}) \\
& \mathrm{C}(\mathrm{x}, \mathrm{y})=\text { cepat rambat gelombang }=\sigma / \mathrm{k} \\
& \mathrm{Cg}(\mathrm{x}, \mathrm{y})=\text { cepat rambat kelompok } \\
& \mathrm{gelombang}=\delta \sigma / \delta \mathrm{k}=\mathrm{nC} \\
& \mathrm{n} \quad=1 / 2(1+(2 \mathrm{kd} / \sinh 2 \mathrm{kd}))
\end{aligned}
$$

Gambar 7 merupakan hasil pemodelan tinggi gelombang signifikan (Hs) dengan inputan tinggi gelombang 4,47 meter (periode ulang 25 tahun) perairan pulau Liwungan secara global. Dari gambar 6 terlihat tinggi gelombang bagian Tenggara pulau Liwungan di bawah 1,5 meter.

Titik-titik pemantauan tinggi gelombang dalam pemodelan di sekitar Pulau Liwungan ditunjukkan dalam Gambar 8, dengan arah dan tinggi gelombang di setiap titik dapat dilihat pada Tabel 4 .

Pada Tabel 4 terlihat arah dan tinggi gelombang berdasarkan pemantauan pemodelan sekitar Pulau Liwungan, dimana tinggi gelombang maksimal berada di titik 1 (bagian Barat Laut Pulau Liwungan) dengan tinggi gelombang antara 3,48 meter sampai dengan 3,68 meter, sedangkan tinggi gelombang minimum 




Gambar 5. Mawar Angin Perairan Pulau Liwungan

Figure 5. Wind rose on Liwungan Island area

Sumber: Hasil pengolahan data

Tabel 3. Input Model Gelombang

Table 3. Wave Model Input

\begin{tabular}{lll}
\hline Arah & $\mathrm{H}$ (meter) & $\mathrm{T}$ (detik) \\
\hline Utara (N) & 4,47 & 15,4 \\
Barat Laut (NW) & 4,47 & 15,4 \\
Barat (W). & 4,47 & 15,4 \\
\hline
\end{tabular}

Sumber: Hasil pengolahan data

berada di titik 3 (bagian tenggara Pulau Liwungan) dengan tinggi gelombang 0,79 meter sampai dengan 1,35 meter.

Secara umum kondisi arah gelombang datang di tampilkan dalam Gambar 9 yang menjalar dari arah Barat Laut ke arah Tenggara Pulau Liwungan. Tinggi gelombang datang pada sisi Barat Laut Pulau Liwungan lebih tinggi dari sisi Tenggara karena sisi Barat Laut Pulau Liwungan tidak terlindungi, sedangkan sisi pulau sebelah Tenggara terlindungi oleh pulau.

\section{Validasi Pemodelan Gelombang}

Metode validasi pemodelan pada penelitian ini dilakukan dengan mengambil titik-titik sepanjang suatu garis dari lepas pantai menuju pantai. Pemodelan dilakukan untuk mendapatkan pola perubahan tinggi gelombang yang menjalar dari laut dalam ke pantai. Validasi dilakukan dengan membandingkan tinggi gelombang pemodelan dengan tinggi gelombang hasil perhitungan analitik dengan persamaan sebagai berikut (Rudyani dkk., 2013):
Persen error relatif $\quad=\left(\mathrm{H}^{\prime}-\mathrm{H} \mid / \mathrm{H}\right) \times 100 \%$

di mana: $\quad \mathrm{H}=\mathrm{H}$ analitik

$\mathrm{H}^{\prime}=\mathrm{H}$ numerik

Dari hasil validasi pemodelan di atas dapat diketahui bahwa perbedaan tinggi gelombang antara hasil pemodelan dengan perhitungan secara analitik memiliki kesalahan maksimal $29 \%$ yang terlihat pada Tabel 5. Sebagai perbandingan untuk nilai kesalahan adalah hasil perbedaan simulasi tinggi gelombang dengan SWAN dan persamaan Young dan Verhagen sebesar 26\% (Akhir \& Mera, 2011).

\section{HASIL DAN PEMBAHASAN}

Pantai Liwungan secara umum mempunyai topografi tergolong landai. Tanah datar berjarak sekitar $10 \mathrm{~m}$ dari bibir pantai. Di sekeliling pulau banyak terdapat gugusan karang tepi (fringing reef) terutama pada bagian barat pulau yang berfungsi sebagai pelindung 


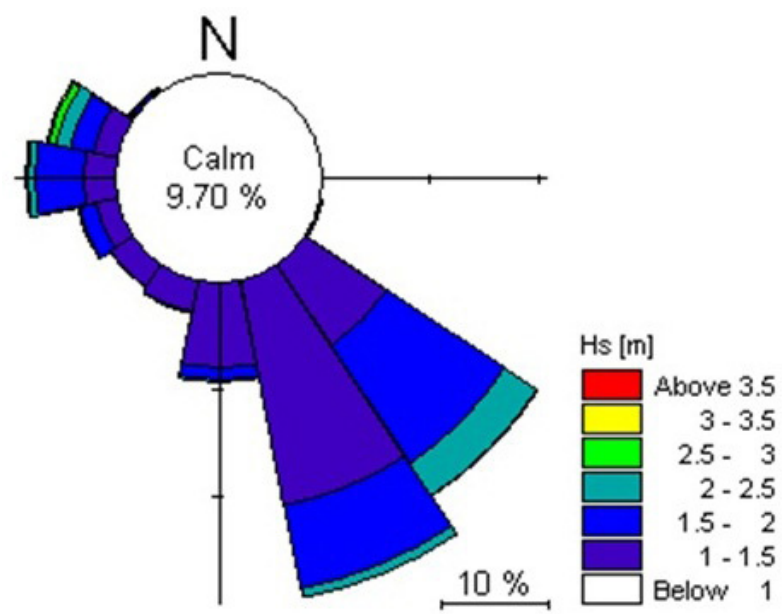

Gambar 6. Mawar Gelombang di perairan Pulau Liwungan

Figure 5. Wave rose on Liwungan Island area Sumber: Hasil pengolahan data



Gambar 7. Model Tinggi Gelombang Signifikan (Hs) Perairan Pulau Liwungan Figure 7. Wave High Significant (Hs) Model on Liwungan Island area

Sumber: Hasil pengolahan data

pantai dari serangan gelombang (Disbudpar, 2013).

Berdasar hasil pemodelan penjalaran gelombang dari laut dalam dengan arah gelombang dari Barat Laut menuju Tenggara, terjadi fenomena difraksi dimana gelombang yang datang terhalang oleh Pulau Liwungan, sehingga gelombang tersebut membelok mengelilingi ujung atau belakang Pulau lalu menuju ke bagian Tenggara Pulau yang berakibat terjadinya peredaman tinggi gelombang di bagian Tenggara 


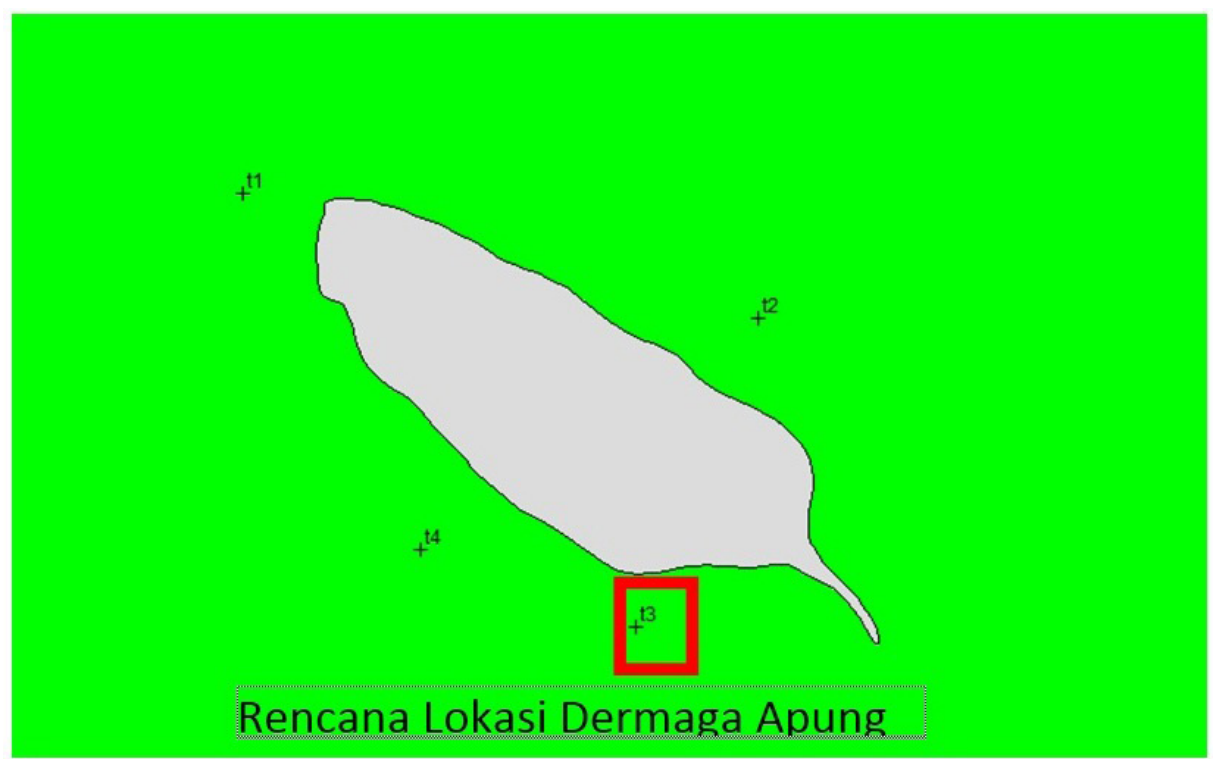

Gambar 8. Titik-titik Pemantauan Gelombang Sekitar Pulau Liwungan Figure 8. Wave observation points of Liwungan Islands area

Sumber: Hasil pengolahan data

Tabel 4. Arah dan Tinggi Gelombang Berdasarkan Titik Pemantauan

Table 4. Wave high and directions based on observation point

\begin{tabular}{llllll}
\hline \multirow{2}{*}{ Titik Pemantauan } & \multicolumn{2}{c}{ UTM } & \multicolumn{2}{c}{ Arah dan Tinggi Gelombang } \\
& $\mathrm{x}$ & $\mathrm{y}$ & Utara (meter) & Barat (meter) & Barat Laut (meter) \\
\hline 1 & 579360 & 9282800 & 3,68 & 2,42 & 3,48 \\
2 & 580200 & 9282600 & 3,45 & 2,35 & 3,27 \\
3 & 580000 & 9282100 & 0,79 & 1,28 & 1,35 \\
4 & 579650 & 9282225 & 2,21 & 2,11 & 2,70 \\
\hline
\end{tabular}

Sumber: Hasil pengolahan data

Pulau Liwungan. Dari analisa tersebut, lokasi yang sesuai untuk pemasangan dermaga apung adalah bagian tenggara Pulau Liwungan, yang mana lokasi tersebut relatif terlindung dari serangan gelombang besar di musim barat. Hasil pemodelan menunjukkan tinggi gelombang di bagian Tenggara Pulau Liwungan berdasarkan titik pemantauan di titik 3 untuk arah Utara sebesar 0,79 meter; arah Barat sebesar 1,28 meter; arah Barat Laut sebesar 1,35 meter.

Fenomena peredaman tinggi gelombang akibat difraksi juga digambarkan oleh hasil peneliti lain, yaitu efek difraksi gelombang yang mengakibatkan tinggi gelombang di bagian belakang pulau lebih kecil (Rabung dkk., 2015).

Penempatan dermaga apung juga mempertimbangkan kedalaman minimum agar tidak kandas pada saat surut terendah. Hasil survei batimetri, kedalaman 1,5 meter di bagian tenggara Pulau Liwungan berjarak tidak jauh dari pantai, sehingga bagian tenggara mempunyai kedalaman yang cukup sesuai untuk penempatan dermaga apung. Kedalaman penempatan dermaga apung juga mempertimbangkan pasang surut perairan Pulau Liwungan yang memiliki tunggang maksimum 1,66 meter. Pertimbangan kedalaman juga untuk mengakomodasi bersandarnya kapal di Pandeglang yang memiliki draft sekitar 1 meter. Sebagai informasi, draft kapal kayu maupun fiber ukuran 3 GT umumnya memiliki draft sekitar 50-60 cm (Nurhasanah, 2016). Untuk efisiensi biaya, dermaga apung ditempatkan pada bagian tenggara pantai yang paling curam, seperti pada gambar 10. Lokasi yang sesuai untuk penempatan dermaga apung yang dimaksud merupakan lokasi yang 


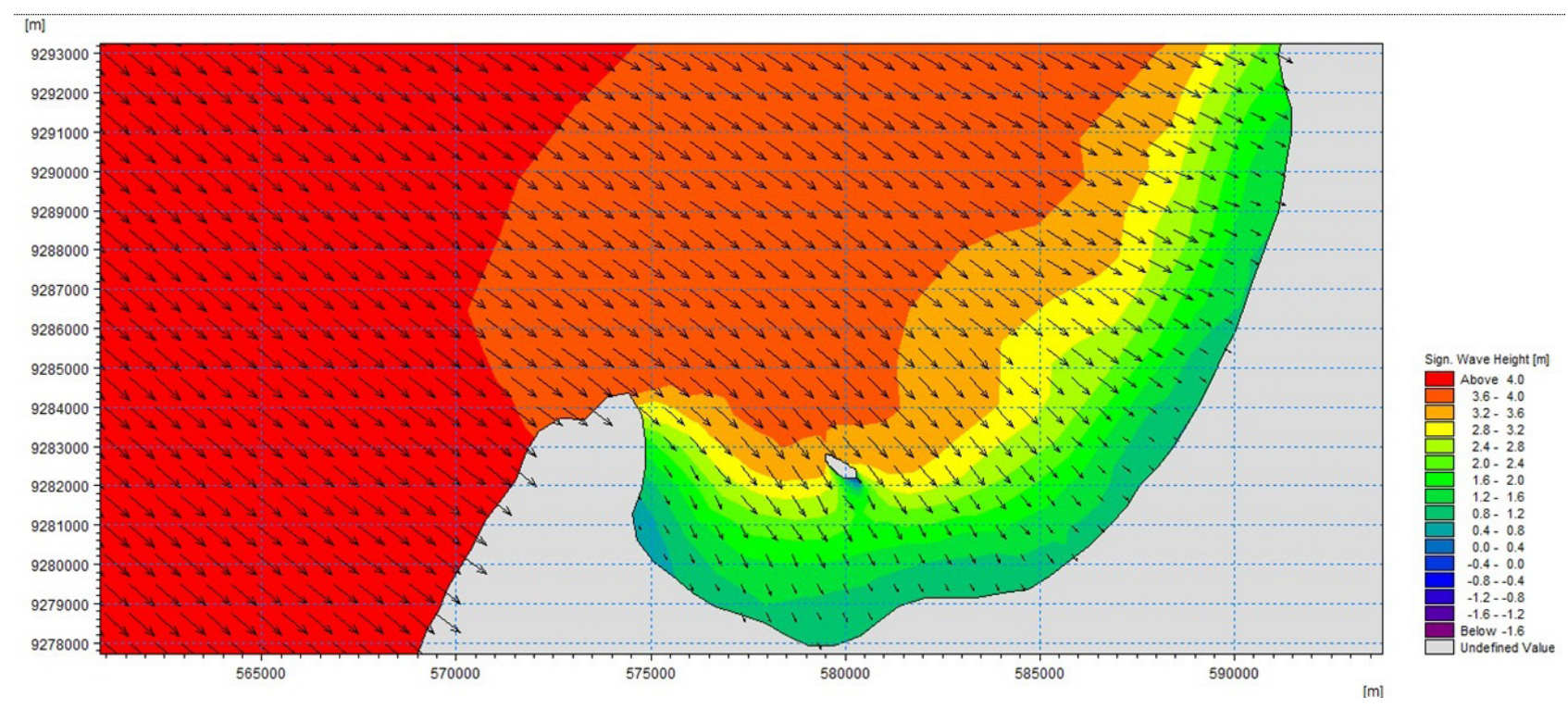

Gambar 9. Gelombang datang arah Barat Laut

Figure 9. Waves coming northwest

Sumber: Hasil pengolahan data

Tabel 5. Hasil Validasi Pemodelan

Table 5. Results of Modelling Validation

\begin{tabular}{ll}
\hline Arah & Kesalahan rata-rata (\%) \\
\hline Utara & 18 \\
Barat Laut & 27 \\
Barat & 29
\end{tabular}

Sumber: Hasil pengolahan data

saat ini sudah ada dermaga kecil dari bahan kayu.

Hasil analisa pada studi ini digunakan sebagai dasar penentuan tata letak (layout) dan model/tipe dermaga apung yang akan digunakan, selanjutnya dilakukan perhitungan struktur dan desain kekuatan dan material dengan memperhitungan beberapa faktor seperti : daya dukung tiang pancang, perhitungan dan analisa pembebanan (hidup dan limpasan gelombang), beban mati (beban struktur, beban lantai/dek dermaga, frame pelindung floater), beban lateral akibat mooring dan berthing kapal digunakan untuk menghitung defleksi tiang pancang akibat tumbukan atau tarikan kapal (pembahasan detail terdapat pada tulisan lain). Konsep layout dermaga apung Pulau Liwungan berdasar hasil analisa diilustrasikan pada Gambar 11 dibawah ini.

\section{KESIMPULAN}

Perairan disekitar pulau Liwungan merupakan perairan moderat dengan tinggi gelombang signifikan berkisar $1,1-2 \mathrm{~m}$ dan rata-rata $1,8 \mathrm{~m}$. Tunggang pasang surut mencapai 1,66 $\mathrm{m}$ dengan tipe pasang surut campuran condong ke harian ganda. Hasil analisa menunjukkan dermaga apung paling sesuai ditempatkan pada bagian Tenggara Pulau Liwungan dimana secara tata letak, perairan tersebut lebih aman dari kemungkinan serangan gelombang dibandingkan bagian pulau yang lain. Bagian pulau tersebut juga paling mudah diakses dari luar karena terletak menghadap Pulau Jawa. Perairan Tenggara Pulau Liwungan juga mempunyai dasar perairan yang lebih curam sehingga desain dermaga apung dapat lebih pendek dengan biaya lebih murah. 




Gambar 10. Lokasi Dermaga Apung di Pulau Liwungan

Figure 10. Floating Floating Location on Liwungan Island

Sumber : Hasil pengolahan data

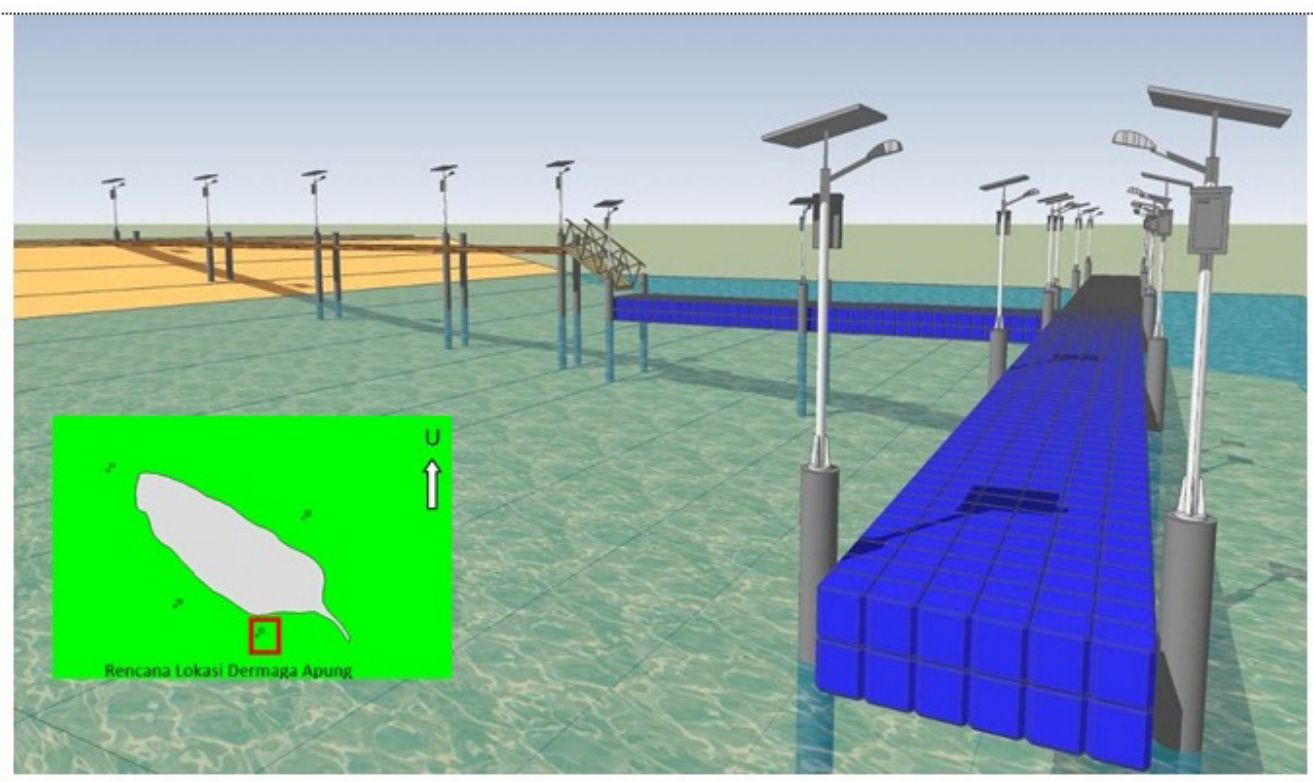

Gambar 11. Layout Model Dermaga Apung di Pulau Liwungan Figure 11. Model of Floating Jetty layout on Liwungan Island Sumber: Laporan akhir, 2015

\section{UCAPAN TERIMA KASIH}

Penulis mengucapkan terima kasih kepada Pusat Riset Kelautan, BRSDMKP untuk penggunaan software MIKE 21 dan Direktorat Pendayagunaan PulauPulau Kecil, Direktorat Jenderal Pengelolaan Ruang
Laut, Kementerian Kelautan Dan Perikanan atas dukungan data yang diberikan sehingga paper ini dapat terselesaikan dengan baik.

Analisa Hidro Oseanografi Pulau Liwungan Untuk Studi Kelayakan Struktur Dermaga Apung - Agus Sufyan, Rudhy Akhwady, Johan Risandi, dan Nurfitri Syadiah 


\section{DAFTAR PUSTAKA}

Akhir. B. \& Mera. M. (2011). Lintasan Gelombang Laut Menuju Pelabuhan Pulau Baai Bengkulu. Volume 7 NO. 2, Oktober 2011. Jurnal Rekayasa Sipil. ISSN: 1858-2133. Universitas Andalas, Sumatra Barat.

Arifiyanto, S. Pranowo, A. RTD. Kuswardani., K.I. Fatoni. (2016). Pengolahan dan Penyajian Data Arus Pasang Surut Hasil Pengukuran Acoustic Doppler Current Profiler (ADCP) SonTek Argonout-XR Menggunakan Perangkat Lunak T_TIDE_V1.3beta. J. Hidropilar 01 (02): 56-67. Chendra, W. (2017). Perencanaan Dermaga Apung Pantai Akkarena. Diakses 11 Nopember 2017, dari https://www.academia.edu/33581764/ Perencanaan_Dermaga_Apung_Pantai_ Akkarena_-_William_Chendra_-_14_34_003.

Cruz. J., (2008). Ocean Wave Energy: Current Status and Future Perspectives. Springer-Verlag Berlin Heidelberg German. 427 pp.

Disbudpar. (2013). Beranda. Pulau Liwungan. Diakses pada tanggal 2 Nopember 2017, dari http:// disbudpar.pandeglangkab.go.id/obwisa-36.html.

Globalmitrateknik. (2017). Pengertian dermaga apung. Diakses 11 Nopember 2017, dari http://www. globalmitrateknik.com/dermaga_apung.html.

Hakiki. I.A., \& Samskerta. I.P. (2016). Aspek Desain Pemecah Gelombang Dan Dermaga Terapung Dengan Menggunakan Sistem Modular. Jurnal Infrastruktur. Vol.02 No.02 Desember 2016. Badan Pengembangan Sumber Daya Manusia. Kementerian Pekerjaan Umum Dan Perumahan Rakyat. Jakarta.

Holthuijsen L.H. (2007). Wave in oceanic and coastal waters. Cambridge University Press.

Kamphuis, J. W. (2000). Introduction to Coastal Engineering and Management. World Scientific, Singapura.

Kramadibrata, S. (1985). Perencanaan Pelabuhan, Ganeca Exact, Bandung.

Laporan Akhir. (2015). Penyusunan Desian Dermaga Apung Di Pulau Liwungan, Kabupaten Pandeglang, Provinsi Banten, Direktorat Pendayagunaan Pulau-Pulau Kecil, Direktorat Jenderal Kelautan Pesisir Dan Pulau-Pulau Kecil, Kementerian Kelautan dan Perikanan, Jakarta.

Muldiyatno, F., E. Djunarsjah, D. Adrianto, W.S. Pranowo. 2016. Kajian Awal Perubahan Muka Air Sungai untuk Penentuan Datum Peta (Studi Kasus Sungai Musi Palembang). J. Chart Datum 01 (02): 36-42.
Muliati Y., Wurjanto, A., \& Pranowo, W. S. (2016). Validation of Altimeter Significant Wave Height Using Wave Gauge Measurement in Pacitan Coastal Waters, East Java, Indonesia. International Journal of Advances in Engineering Research 12(4): 25-33.

Mustikasari, E., L.C. Dewi, A. Heriati, \& W.S. Pranowo. (2015). Pemodelan Pola Arus Barotropik Musiman 3 Dimensi (3D) Untuk Mensimulasikan Fenomena Upwelling di Perairan Indonesia. J. Segara 11(1): 25-35.

Nurhasanah. (2016). Evaluasi Perbandingan Draft Kapal Ikan Fiberglass Dan Kayu Berdasarkan Skenario Loadcase, Studi Kasus Kapal Ikan 3GT. Jurnal Ilmu Pengetahuan dan Teknologi Kelautan. KAPAL, Vol. 13, No.2 Juni 2016. eISSN: 2301-9069.

Owens, E.H. (1982). Sea conditions. In: Beaches and Coastal Geology. Encyclopedia of Earth Science. Springer, Boston, MA.

Pariwono, J.I. (1989). Kondisi Pasang Surut di Indonesia. Kursus Pasang Surut. P3O-LIPI. Jakarta.

Poerbandono \& Djunarsjah, E. (2005). Survey Hidrografi. Refika Aditama, Bandung.

Pranowo, W.S. \& S. Wirasantosa. 2011. Tidal regims of Arafura \& Timor Seas. Journal of Marine Research in Indonesia 36(1): 21-28.

Rabung. F., Muhiddin. A.b., Hatta. M.P., Malik. S. (2015). Deformasi Gelombang Di Pantai Makassar. Prosiding 2015. Hasil Penelitian Teknologi Terapan. Volume 9 : Desember 2015. ISBN : 97 8-9 79-12 7255-0-6

Rudyani, F.P., Armono, D.A. \& Sujantoko. (2013). Pemodelan Gelombang di Kolam Pelabuhan Perikanan Nusantara Brondong. JURNAL TEKNIK POMITS Vol. 2, No. 2, (2013) ISSN: 2337-3539. Surabaya

Saputra, E.P.A., W.S. Pranowo, A.P. Wiryawan, D. Adrianto. (2016). Pengaruh Sound Velocity Terhadap Pengukuran Kedalaman Menggunakan Multibeam Echosounder di Perairan Surabaya. $J$. Chart Datum 2 (2): 53-68.

Sciortino, J.A. (2010). Fishing Harbour Planning, Construction and Management. FAO Fisheries and Aquaculture Technical Paper (FAO), no. 539 / FAO, Rome (Italy). Fisheries and Aquaculture Resources Use and Conservation Div. Accession No: 449445, Job No: I1883, ISBN 978-92-5106696- 6 , ISSN 2070-7010, Call No: S238 30 ENG.ED (LIB).

Supriyono, Pranowo, W.S., Rawi, S., \& Herunadi, B. (2015). Analisa dan perhitungan prediksi pasang 
surut menggunakan metode Admiralty dan metode Least Square (Studi kasus Tarakan dan Balikpapan). J. Chart Datum 1(1): 8-18.

Syaifuddin, Siswanto. A.D., Hidayah. Z. (2016). Karakteristik Gelombang Di Perairan Kalianget Kabupaten Sumenep. Prosiding Seminar Nasional Kelautan 2016 Universitas Trunojoyo Madura, 27 Juli 2016.

Triatmodjo, B. (1999). Teknik Pantai. Beta Offset, Yogyakarta.ISBN: 979-8541-05-7.

Umpel, I.F., Mamoto, J.D, Jasin. M.I. (2015). Studi Karakteristik Gelombang Pada Daerah Pantai Matani Satu. Jurnal Sipil Statik Vol.3 No.9 September 2015 (651-661) ISSN: 2337-6732.

Watanabe, E., Wang, C., Utsunomiya, T., \& Moan, T. (2004). Very Large Floating Structures: Applications, Analysis And Design. Singapore: Centre for Offshore Research and Engineering National University of Singapore.

Young, I.R. (1999). Wind Generated Ocean Waves. Elsevier. ISBN: 978-0-08-043317-2 